\title{
ナノ結晶粒界の品質評価と物性制御への適用
}

$$
\text { 村田直一 }{ }^{* 1} \text {, 鈴木 } \text { 研 }^{* 1} \text {, 三浦 英生 }{ }^{* 1}
$$

\section{Quantitative Evaluation of the Crystallinity of Grain Boundaries in Nano-scale and its Application to the Control of Material Properties}

\author{
Naokazu MURATA ${ }^{* 1}$, Ken SUZUKI ${ }^{* 1}$ and Hideo MIURA ${ }^{* 1}$ \\ *1 Tohoku University, Fracture and Reliability Research Institute \\ 6-6-11 Aoba, Aramaki, Aobaku-ku, Sendai, Miyagi, 980-8579 Japan
}

In this study, a novel method for evaluating the crystallinity of a grain boundary is proposed based on the definition that a grain boundary consists of a finite volume with disordered atomic configuration. An electron beam-scattering diffraction (EBSD) method is applied to the evaluation of the crystallinity. The effectiveness of the proposed method is validated by the application of this method to the crystallographic characterization of electroplated copper thin films. The crystallinity of grains and grain boundaries was evaluated by $I Q$ (Image Quality) value of EBSD analysis. Thin film interconnections for measurement of electrical properties were prepared based on damascene process. The crystallinity of the interconnection without annealing was low. The crystallinity of interconnection was improved by annealing at $400^{\circ} \mathrm{C}$ for 30 minutes. Though the EM (Electro-Migration) resistance of the annealed film was improved drastically, SM (Stress-induced Migration) was activated even though interconnection was kept at room temperature without any application of electrical current after annealing. This is because high residual stress was caused by shrinkage of electroplated copper due to change of crystallinity. Thus the control of the crystallinity of the electroplated film was very important to improve the reliability of the interconnection.

Key Words : Reliability, Grain Boundary, Micro Texture, Electroplated Copper, Crystallinity

\section{1. 粕 言}

各種構造材料で使用される材料寸法あるいは結唱組織の微細化に伴い, 結唱粒界近傍の微細組織に依存して材 料物性が大きく変動する傾向が顕在化している. 著者らは, LSI 用0微細薄膜配線に用いられるめっき銅薄膜に おいて, 微細組織を構成する結晶粒と結晶粒界の品質がめっき条件とその後の熱履歴に依存して大きく変化し, 特に結奛粒界の品質に依存して，1）膜のマイグレーション耐性が大きく変化すること，2）機械的な硬さや疲 労強度特性が脆性的な不安定特性から延性的な安定した特性まで複雑に変化すること，などを報告してきた 1). このような電気・機械的特性の変動が不規則に製品で生じた場合, 製品の寿命にも大きな分布やばらつきが生じ ることが懸念されることから，物性変動メカニズムの解明とその制御方法の確立は製品の信頼性や性能向上を図 る上で不可欠である. 特に, 物性変動の主要因子である結晶粒界組織に関し, 結晶粒界における原子配列長周期 構造の定量的な評価と結晶粒界の品質制御が重要である。そこで本研究では, 後方電子散乱回折（Electron Backscatter Diffraction: EBSD）法に抠りる電子線回折現象に基づいた菊池パターン形成メカニズムを応用し，集束 電子線の二次元走查による極微回折像を取得することにより，ナノレベルで結㫛粒界品質を評価する手法を提案 する.ささらにここの評価手法を用いて，めっき銅薄膜配線の高性能・高信頼化を実現するための設計指針及び結晶 粒界品質制御手法を提案した概要を報告する.

\footnotetext{
*1 正員, 東北大学大学院工学研究科附属エネルギー安全科学国際研究センター（テ980-8579 仙台市青葉区荒巻字青葉 6-6-11）

E-mail: naokazu.murata@rift.mech.tohoku.ac.jp
}

[No.12-1］日本機械学会 2012 年度年次大会講演論文集 [2012.9.9-12, 金沢] 


\section{2. 結晶粒界品質の評価}

EBSD 法は, 電子線を照射した際に発生する後方電子散乱回折像（菊池パターン）を用いて, 試料表面の結晶 方位の同定を行う結晶品質の分析方法であり, ナノ・マイクロスケールの微小領域における結晶粒の異方性に起 因した変形や破壊のメカニズム解明に非常に有効な手法であるため, 鉄鋼などの構造材料から LSI 用配線構造材 料である薄膜材料まで幅広い材料分野に適用されている．しかしながら, EBSD 解析では, 粒界方位の特定に明 瞭な菊池パターンを得る必要があるため，ある一定の結晶品質を有する測定領域では適切な方位情報が得られる ものの，明瞭な菊池パターンが確認されない結晶性の低い領域，例えば結晶粒界の 3 重点近傍では適切な評価が 困難であることが知られている．したがって，結晶粒界の方位関係を明らかにする目的でEBSD 解析法を用いた 場合, 試料中の低結晶品質領域は結晶方位解析が困難であるという理由から, 結晶粒界もしくはその近傍におけ る結晶品質の評価はこれまで行われてこなかった．これに対し本研究では，従来無効なデータとして扱われてき た低結晶品質領域から得られる電子線回折強度を評価することにより，結晶粒界品質の評価が可能になるものと の着想に至った。

本研究で提案する粒界品質評価手法では，㐘池バンドの濃淡情報（鮮明度）を分析することで電子線照射領域 における結晶性の評価ができると考え, EBSD 法によって得られる $I Q$ (Image Quality) 值と $C I$ (Confidence Index) 值を評価バラメータとして使用する. $I Q$ 值は，菊池パターンを二次元画像情報から線情報を抽出する八フ変換に 基づいて評価する指数であり，各菊池線の鮮明度を数值化し，その領域平均值としてまとめたものである. 菊池 線は入射電子線と結晶格子の干渉により生じるので，結晶格子の品質（原子配列の秩序性）が高いほど鮮明にな る，したがってこの $I Q$ 值は，電子線照射領域における結晶品質を反映した数值と考えてよく，本評価手法では $I Q$ 值を結晶品質評価指数として使用し， $I Q$ 值が高い測定領域を結晶性が高い領域， $I Q$ 值が低い領域を結晶性が 低い領域と定義する．もう一つの評価パラメータである $C I$ 值は, 測定領域（電子線照射領域）における結晶方位 の信頼性を示寸指標である．例えば測定領域に異なる結晶方位を持つ複数の結晶粒が存在する場合，測定領域の 結晶方位を一つに特定することができないため, 方位データの信頼性の指標である $C I$ 值は低くなる.したがって, $C I$ 值が低い測定領域は単一結晶領域ではない，すなわち結晶粒界領域とみなすことができるため，本評価手法で は, $C I$ 值を結晶粒界位置特定指数として測定領域に执洁晶粒界の存在の有無の判別に用いることとした.

\section{3. めっき銅薄膜配楾の結晶性評価と電気特性制御への適用}

\section{1 評価試料の作憋}

提案する結晶粒界品質評価手法の有用性の検証と次世代半導体配線の高性能・高信頼性化を目的として，薄膜 配線の電気特性, 長期信頼性と結晶粒界品質との相関性を検証するとともに, 薄膜配線の高信頼化を達成する最 適化プロセスの提案への適用を試みた。銅配線の電気特性として電気低効率とエレクトロマイグレーション

（EM）而性を評価した. 評価用薄膜配線試料は, 2 インチのSi基板トに厚さ約 $1 \mu \mathrm{m} 0$ Si酸化膜を堆積し, 幅 $8 \mu \mathrm{m}$, 長さ $1600 \mu \mathrm{m}$ の配線形成溝をエッチング加工し，バリア層としてTaを $120 \mathrm{~nm}$, 電解めっきのシード層としてCuを $30 \mathrm{~nm}$ それぞれ真空蒸着法で堆積した後, 電流密度を $10,30,50 \mathrm{~mA} / \mathrm{cm}^{2}$ と変化させ電解めっき法によって溝内部 に銅薄膜を成膜して試作した．めっき液は純水 $779 \mathrm{~g} /$ ，硫酸 $157 \mathrm{~g} /$ l, 酸化銅 $64 \mathrm{~g} /$ を混合させたもので，他の添加闵等は 一切加えてはいない，めっき後，一部の配線は $400^{\circ} \mathrm{C} ， 3$ 時間, $\mathrm{Ar}$ 雰囲気中で熱処理を施し, 熱処理と未熱処理の二 種類の試料を準備した．溝外部に堆積された膜は，ダイヤモンドペーストを用いて機械研磨で除去し，残留ひず み除去のために電解研磨を施し測定に供した。配線の電気抵抗は 4 端子法を用いて測定した。試作した薄膜配線 の概略模式図と断面模式図を図1 に示寸.
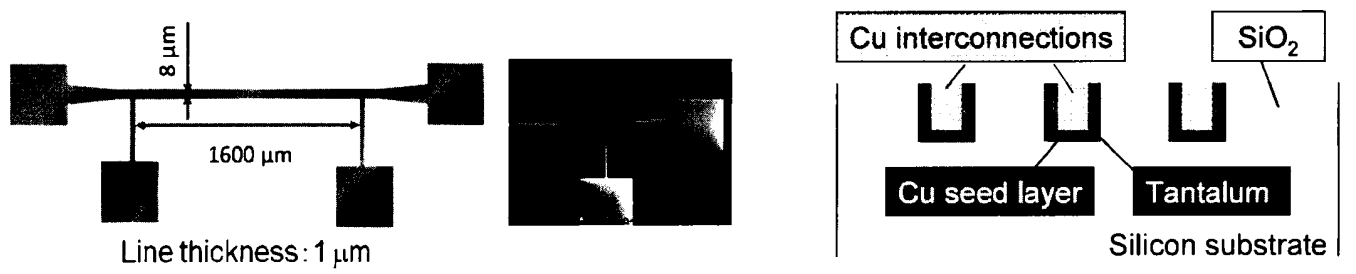

Fig. 1 Sectional view and SEM image of the sample interconnection 


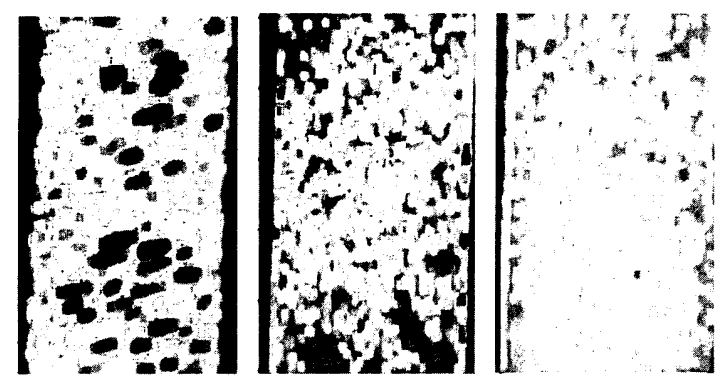

$10 \mathrm{~mA} / \mathrm{cm}^{2}$

$50 \mathrm{~mA} / \mathrm{cm}^{2}$

Fig. 2 Effects of the current density during electroplating on the distribution of IQ value in the $\mathrm{Cu}$ thin film interconnections

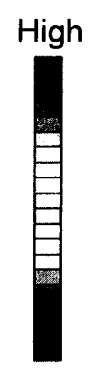

Low

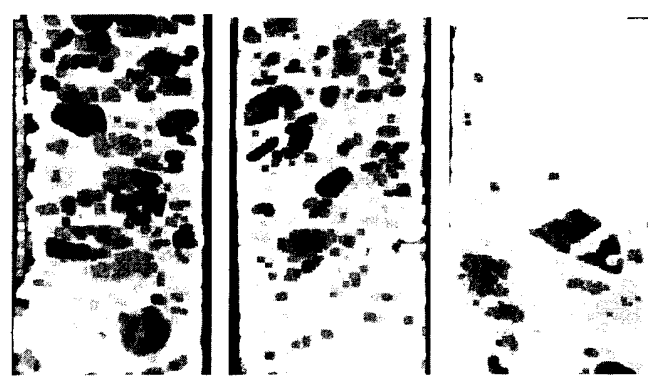

$10 \mathrm{~mA} / \mathrm{cm}^{2} \quad 30 \mathrm{~mA} / \mathrm{cm}^{2} \quad 50 \mathrm{~mA} / \mathrm{cm}^{2}$

Fig.3 IQ map of the $\mathrm{Cu}$ thin film interconnections after annealing at $400^{\circ} \mathrm{C}$

\section{2 結晶品䨘評価}

図 2 に各めつき条件で作製した木熱処理の薄膜配線における $I Q$ 值分布図を示寸．めっき時電流密度が減少す るにつれて, 低 $I Q$ 值の領域 (青色の領域)が減少していき, 高い $I Q$ 值の領域(赤色の領域)が増加していることが 確認できる. $C I$ 值分布と比較したところ低 $I Q$ 值の領域は低 $C I$ 值領域 $(<0.3)$ であったことから, 低 $I Q$ 值の領 域は疎な結晶粒界または微細結晶と考えられる.つまり，めっき時の電流密度が $50 \mathrm{~mA} / \mathrm{cm}^{2} や 30 \mathrm{~mA} / \mathrm{cm}^{2}$ の配線 は, 低 $I Q$ 值領域が大部分を占めていることから, 結晶品質の低い疎な粒界や，微細結晶が配線内の大部分を占 めていると考えられる. 一方, めっき時の電流密度が $10 \mathrm{~mA} / \mathrm{cm}^{2}$ の配線では高 $I Q$ 值領域が増えており, 転位な どの結晶欠陥の少ない，原子配列の周期性が良好な構造を有寸る高品質な結晶の割合が増加していることが確認 できる．同様の品質評価を熱処理を施した銅めっき配線に対しても行った．図 3 に熱処理後の配線におけるIQ 值の色等高線図を示す. 熱処理前と熱処理後を比較すると全ての配線試料において赤色の領域(高 $I Q$ 值領域)が増 加しており，結晶品質の低い疎な結晶粒界が消失し，結晶粒の粗大化が生じていることが確誌できる. 特に 10 $\mathrm{mA} / \mathrm{cm}^{2}$ の配線では高 $I Q$ 值領域が大部分を占めており, 配線全体が高品質な結晶粒で構成されていることが確認 できる．したがって，熱処理の過程で生じる再結晶化反応で，平均結晶粒径の増加にとどまらず，各結晶の結晶 品質も向たしていることが明らかになった。このように，本研究で提案した結晶粒界品質評価法を用いることに よって，めっき時の電流密度を減少させ，めっき後熱処理を施すことにより，結晶品質の低い疎な結晶粒界の占 積率が減少し，結晶粒が粗大化するとともに結晶粒内の品質も向上していることが確認できた.

\section{3 電気的特性の評価}

四端子法を用いてめっき時の電流密度を変化させた銅めっき薄膜配線の電気抵抗を, 基板温度 $30^{\circ} \mathrm{C}$, 測定電流 $8 \mathrm{~mA}$ の条件で測定し, 配線の断面積から電気抵抗率を算出した。 めっき時電流密度変化に伴う電気抵抗率の変 化を図 4 に示す。 めっき時の電流密度が減少寸るに従って, 電気抵抗率む単調に減少した. 図 5 に銅めっき配線 の平均 $I Q$ 值（測定領域平均）と電気抵抗率の関係を示寸，最も高い平均 $I Q$ 值を示した試料は，めっき時電流密 度 $10 \mathrm{~mA} / \mathrm{cm}^{2}$ で熱処理を施したものであり，その電気抵抗率は約 $2 \times 10^{-8} \Omega \mathrm{m}$ であった. 平均 $I Q$ 值が上昇するにつ れて電気抵抗率が低くなっていることから, 薄膜配線の電気的特性と $I Q$ 值による結晶品質の間には強い相関関 係が存在することが確認された。これは，金属等の電気抵抗率は，電子の流れを阻害する欠陥（空孔，転位，結 晶粒界）の占積率に強く依存するためであり, 結晶粒界等の格子久陥は電子の散乱中心となるので, 不純物や， 転位密度, 結晶品質の低い疎な結晶粒界を有するめつき銅配線で電気抵抗率が増加したものと考えられる，バル ク材と銅めっき配線を比較すると，銅めっき配線の電気抵抗率はバルク材よりも大きいことがわかる．めっき法 で形成された銅配線の問題として, バルク材から期待された性能, 電気抵抗率やエレクトロマイグレーション耐 性など，が得られないことが知られているが，本研究で作製した銅めっき配線においてもバルク材とは異なる高 い電気抵抗が得られた。しかし，銅めっき配線の結晶品質が高まるにつれて電気抵抗率は低くなり，良好な電気 特性を示すようになることから，めっき時電流密度の減少及び熱処理により結晶品質を向上させることによって バルク材に近い性能を引き出すことが可能であると考えられる.

結晶品質のエレクトロマイグレーション而性への影響を解明するために，電流密度 $30 \mathrm{~mA} / \mathrm{cm}^{2}$ でめっきした銅薄膜配 線の熱処理試料と末熱処理試料に対してエレクトロマイグレーション試験を行った. 負荷電流密度(を $10 \mathrm{MA} / \mathrm{cm}^{2} て ゙, 10$ 


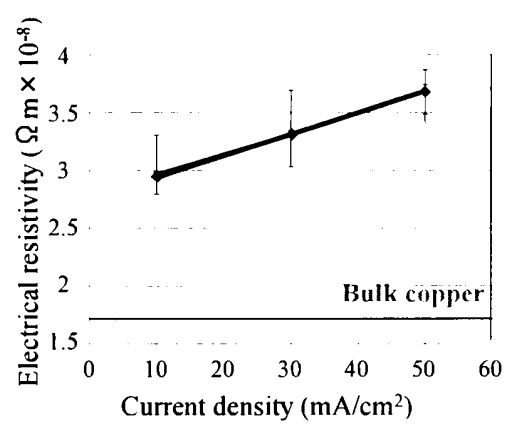

Fig. 4 Current density dependence of the electrical resistivity of $\mathrm{Cu}$ thin film interconnections

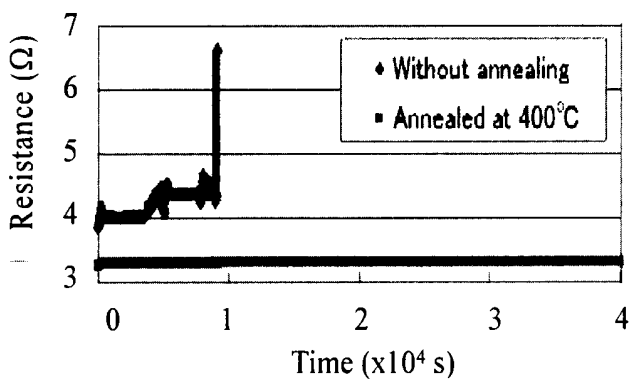

Fig. 6 Example changes of the resistance of thin film interconnections during the electro-migration test

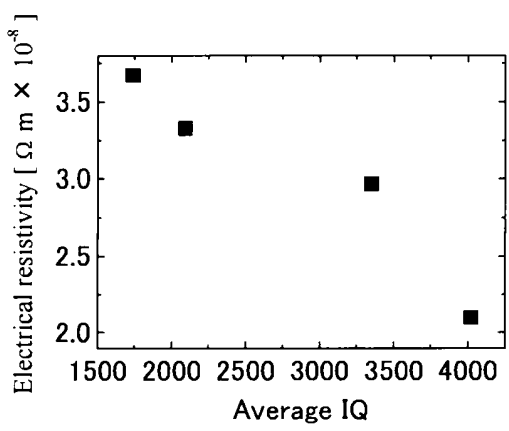

Fig. 5 Electrical resistivity of $\mathrm{Cu}$ thin film interconnections as functions of the average IQ values

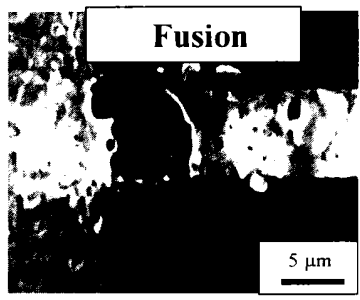

(a) Without annealing

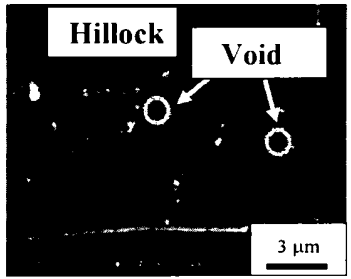

(b) Annealed at $400^{\circ} \mathrm{C}$
Fig. 7 SEM photographs of the surface of the film after the electro-migration test

時間通電し，その間の抵抗值変化を測定することでエレクトロマイグレーション而性を評価した. エレクトロマイグレ ーション試験の結果を図 6 に示す. 未熱処理の配線では，通電直後から電気抵抗が増加し，数時間で抵抗值が急激に上 昇し，破断に至っている. これに対し，熱処理を施した配線試料では，数時間抵抗増加を起こさず，急速破断を起こさ なかった.このことから，熱処理によってェレクトロマイグレーション而性が向トレていることが理解できる. 龱 $7 に$ 通電後の表面性状を示す．未熱処理の配線では溶断の跡が確認できる．これは，めつき膜内に存在する結晶品質の低い 疎な結晶粒界によって，配線内の電子の流れが局所的に阻害され，局所的に電流密度が増加し，ジュール発熱により溶 断してしたものと考えられる，一方，熱処理後の配線では，表面にボイド，ヒロックの発生が確認できるものの溶断は 生じなかった：これは，熱処理により結晶品質が向上したことで電子が容易に結晶粒界を通過できるようになり，配線 を溶断させるほどのジュール熱は膜中に発生せず, エレクトロマイグレーションによってボイドやヒロックが発生し たと考えられる.この結果は，結晶品質向上によるエレクトロマイグレーションの発生を裏付けており，結晶品質とエ レクトロマイグレーション耐性の間には相関関係にあることが示された.

\section{4. 結言}

本研究では，結晶粒界品質詊価方法の有用性の検証と次世代半導体配線の高性能・高信頼性化を目的として， 電気特性，長期信頼性と結晶粒界品質との相関性を検証した。その結果，電気抵抗率，エレクトロマイグレーシ ヨン而性と結晶品質に強い相関性が確認され，電気抵抗率の低減やエレクトロマイグレーション而性の向上など高信 頼性銅めっき薄膜配線の設計には, めっき時電流密度の減少と熱処理による結晶及ひ結晶粒界品質の向上が必要不可 欠であることが確認された．また，本研究で提案した結晶粒界品質評価手法によって，電気特性と結晶組織（結晶品質） の関係が初めて定量的，視覚的に明らかになり，本提案手法の有効性を実証した.

\section{文献}

(1) Naoki Saito et al., "Mechanical and Electrical Reliability of Copper Interconnections for 3DIC", IEEE International 3D System Integration Conference 2011 (3DIC 2011), Proceedings CD-R, P-1-25, pp.1-6. 